DOI: 10.34015/2523-4552.2019.4.02

УДК 342.7

Кругова C. C., аспірантка Інституту держави і права імені В. М. Корецького НАН України ORCID: 0000-0002-5488-6754

\title{
НАУКОВА ІНТЕРПРЕТАЦІЯ ЗАБЕЗПЕЧЕННЯ РІВНОСТІ ПРАВ І СВОБОД ЖІНОК ТА ЧОЛОВІКІВ В УКРАЇНІ
}

У статті підкреслюється, що забезпечення рівності прав чоловіків та жінок доцільно визначити як сукупність нормативно визначених гарантій щодо забезпечення рівних прав для представників різних статей, впровадження рівних можливостей у реалізації своїх прав як чоловіками, так і жінками у всіх сферах життєдіяльності суспільства із врахуванням особливостей кожної статі з метою економічного, політичного, соціального і культурного розвитку особистості та діяльність органів державної влади зі створення умов, необхідних для відповідного забезпечення з боку держави.

Ключові слова: нормативно-правові акти; заробітна плата; особистість; реалізація прав; правове забезпечення.

В статье подчеркивается, что обеспечение равенства прав мужчин и женщин целесообразно определить как совокупность нормативно определенных гарантий по обеспечению равных прав для представителей разных полов, внедрение равных возможностей в реализации своих прав как мужчинами, так и женщинами во всех сферах жизнедеятельности общества с учетом особенностей каждого пола с целью экономического, политического, социального и культурного развития личности и деятельность органов государственной власти по созданию условий, необходимых для соответствующего обеспечения со стороны государства.

Ключевые слова: нормативно-правовые акты; заработная плата; личность; реализация прав; правовое обеспечение.

Постановка проблеми. Принцип рівності має один із безпосередніх проявів щодо однакового підходу до чоловіків та жінок, тобто рівності прав чоловіків та жінок, або, як визначають в науці, гендерної рівності. Відповідний прояв увійшов до загального принципу рівності як діалектичного поєднання концепцій формальної і фактичної (реальної) рівності, та $є$ його невід'ємною частиною, поряд із забезпеченням рівності незалежно від місця народження та проживання, кольору шкіри, політичних, релігійних та інших переконань, статі, етнічного й соціального походження, майнового стану та інших ознак. Встановлення гендерної рівності пов'язується зі змінами статусу чоловіка та жінки, що перебуває в залежності від окремих стереотипних уявлень про їх ролі в традиційному суспільстві. Саме незавершеність відповідних перетворень зумо- 
влює дисбаланс та відсутність однозначності уявлень про моделі поведінки чоловіків та жінок. При цьому усталеність уявлень про соціальні ролі й моделі поведінки чоловіків та жінок уповільнюють прогрес у забезпеченні рівними правами осіб, незалежно від належності їх до окремої статі.

3 отриманням Україною незалежності та обранням нею демократичного шляху розвитку одним із основоположних питань стало регулювання рівності прав і свобод жінок та чоловіків. Зазначимо, що успішний розвиток та формування сучасної правової системи України повинні грунтуватися на усвідомленні цінності людського життя, важливості повноцінного та гармонійного розвитку кожної особистості, забезпеченні прав людини, необхідності створення умов для самореалізації людського потенціалу, в тому числі за умови забезпечення гендерної рівності. А відтак, через унормування та дотримання положень щодо неупередженого ставлення до особи за ознакою статі можливий сталий розвиток суспільства.

На перший погляд, Україна $€$ державою, в якій належним чином врегульовано питання забезпечення рівності прав і свобод жінок та чоловіків. Гендерна дискримінація заборонена Конституцією України [1]. Прийнято низку нормативноправових актів, у яких встановлено рівність жінок та чоловіків у правах (наприклад, Закон України «Про забезпечення рівних прав та можливостей жінок і чоловіків» [2]). На рівності жінок та чоловіків в Україні постійно наголошується політиками та експертами. Але як свідчать статистичні дані, на практиці забезпечення рівності прав і свобод жінок та чоловіків в Україні все ще є проблемним питанням. Так, 3 моменту здобуття Україною незалежності співвідношення частки зайнятості серед жінок до аналогічного показника серед чоловіків зменшується: від майже $82 \%$ в 1999 р. до 74,5 \% в 2017 р., а найнижчий показник становив $74 \%$ у 2012 році. Це означає, що жінки в Україні завжди відігравали менш активну роль у формальній економіці, а отже, отримували менше економічних ресурсів [3]. Іншим показником гендерної нерівності в Україні $€$ розрив у оплаті праці між чоловіками та жінками. Так, у період між 2000 р. та 2016 р. різниця між оплатою праці коливалася від $31,4 \%$ у 20032004 рр. до $22,2 \%$ у 2010 році. Із 2004 р. розрив в оплаті праці загалом скорочувався, проте в розпал кризи в 2015-2016 рр. знову суттєво збільшився [3]. Іншим показником гендерної нерівності чоловіків та жінок в Україні $є$ те, що у період кризи заробітна плата жінок девальвувала більше, ніж зарплата чоловіків: заробітна плата чоловіків у 2015 р. становила $87,7 \%$ від заробітної плати 2013 р., тоді як заробітна плата жінок - 77,3 \% від показника того ж року. Це означає, що зарплата жінок постраждала від девальвації на 10 \% сильніше, ніж заробітна плата чоловіків. Це варто пояснити тим, що в середньому жінки заробляють менше чоловіків, тож серед них більше тих, хто отримує мінімальну зарплату, а її було заморожено з початком кризового періоду [3]. Разом із тим у ст. 2-1 Кодексу законів про працю України [4] встановлено рівність трудових прав громадян України, у тому числі заборону прямого або непрямого обмеження прав праців- 
ників залежно від гендерної ідентичності. Наведені статистичні дані свідчать про те, що навіть у тих сферах, в яких прямо встановлено заборону гендерної дискримінації, на практиці вона все ж має місце. Тому дослідження питань, пов'язаних із забезпеченням рівності прав і свобод жінок та чоловіків в Україні, не втрачають своєї актуальності.

Аналіз останніх досліджень і публікацій. Питання, пов'язані із науковою інтерпретацією та особивостями забезпечення рівності прав і свобод жінок та чоловіків в Україні регулярно потрапляють у сферу наукових інтересів вітчизняних науковців. Зазначимо внесок у розробку наукової теорії гендерної рівності таких вчених, як: І. П. Андрусяк, Н. В. Аніщук, Н. Б. Болотіна, Н. О. Бондаренко, М. В. Буроменський, Н. С. Власенко, Т. М. Головко, І. М. Грабовська, І. О. Грицай, Н.В.Грицяк, С. М. Гришак, О. Р. Дашковська, Т. Р. Деметрадзе, Т. Ю. Журженко, В. І. Івченко, Л. О. Козуб, А. І. Кормич, Т. М. Краснопольська, М. І. Крочук, Н. В. Лавриненко, К. Б. Левченко, О. В. Литвинчук, Т. О. Марценюк, Т. М. Мельник, O. А. Мірошніченко, С. М. Оксамитна, Т. В. Омельченко, Н. М. Оніщенко, О. М. Рудік, О. М. Руднєва, Т. І. Фулей та багатьох інших дослідників. Разом із тим проблема забезпечення рівності праві свобод жінок та чоловіків в Україні до цих пір залишається актуальною. Враховуючи, що необхідність глибокого аналізу впровадження принципу гендерної рівності, виокремлення проблемних питань в регулюванні даного питання та подальше їх вирішення обумовлена потребою подальшого формування України як країни з високим соціальним рівнем життя та демократичними цін- ностями, наше дослідження $\epsilon$ необхідним та важливим.

Постановка завдання. Метою статті $\epsilon$ формулювання наукової інтерпретації забезпечення рівності прав і свобод жінок та чоловіків в Україні.

Виклад основного матеріалу. Юридична рівність - це встановлена в законі рівність суспільного становища людей, прав та обов'язків громадян і однаковий ступінь відповідальності осіб, що виключає будь-які переваги чи привілеї окремих осіб.

Для виокремлення гендерної рівності та її дослідження важливим елементом $\epsilon$ аналіз основи змісту даного поняття. Зазначимо, що забезпечення рівності в досліджуваній темі пов'язується із диферентціацією окремих індивідів за їх статевою ознакою, відтак з метою наукового дослідження важливим $є$ визначення та виокремлення даної ознаки в окрему категорію, якою на науковому рівні $є$ категорія «гендер».

Англійське слово «gender» означає рід як граматичний рід або вид у розумінні належності до певного класу. Застосування цього терміна покликано відрізнити «соціальну стать» від біологічної. Українська мова не містить чіткого еквівалента даного слова, відтак виникають відмінні різночитання. Використовуючи слово «стать», передусім виділяється біологічна природа особи. Однак i функціонування $\epsilon$ не лише предметом біологічних законів, а й ряду культурних стереотипів, що і $є$ предметом дослідження гендерних відносин [5, с. 47]. Поняття гендеру $\epsilon$ більш широким аніж поняття статі, оскільки в його зміст включається більший обсяг ознак, зокрема певні культурні стереотипи. Фактично 
поняття статі обмежується визначенням особливостей особи лише щодо наявності у неї окремих фізіологічних ознак. При формуванні поняття гендеру необхідно враховувати більш широкий обсяг можливих ознак.

У науковій літературі зустрічаються терміни «стать» та «гендер», однак слід вказати, що вони - не тотожні поняття, хоча і $\epsilon$ суміжними. Майкл С. Кіммел пояснює цю проблему таким чином: «Стать стосується біологічного апарату, чоловічої й жіночої особин, тобто нашої хромосомної, хімічної та анатомічної будови. Гендер пов'яза-ний зі змістом, що його ми вкладаємо у відповідні відмінності в рамках культури. Стать це самець і самиця; гендер - це маскулінність і фемінність: чоловічність і жіночність - те, що означає бути чоловіком чи жінкою. Біологічна стать має дуже незначну варіативність, тоді як гендер варіюється надзвичайно» [6, с. 3-4]. Тобто, автор розкриває поняття статі саме через біологічні особливості особи, в той же час наділяючи гендер проявами статі у чоловічності чи жіночності. Вважаємо дану позицію зваженою, оскільки прояви статі $є$ окремими суб'єктивними ознаками, якими суспільство наділяє окрему стать, вважаючи це усталеними для неї стандартами.

Подібні позиції щодо поняття гендеру віднаходимо і в іншій науковій літературі, де зазначається, що гендер - це змодельована суспільством та підтримувана соціальними інститутами система цінностей, норм і характеристик чоловічої і жіночої поведінки, стилю життя та способу мислення, ролей та відносин жінок і чоловіків, набутих ними як особистостями в процесі соціалізації, що насамперед визначається соціальними, політичними, економічними і культурними контекстами буття й фіксує уявлення про жінку та чоловіка залежно від їхньої статі [7, с. 11]. Таким чином, поняття гендеру, як набору певних характеристик та ознак окремої статі, має досить широке розуміння, зокрема щодо кількості та розгалуженості напрямів для виокремлення ознак, які становлять зміст поняття гендеру. Основним, на нашу думку, є визначення соціальної ролі за окремою статтю, що в подальшому відображається на різних сферах діяльності в процесі їх життя та становлення. Відповідне від ображення, на підставі соціальної ролі статі, формує розуміння про неї.

Т. В. Герасименко розглядає гендер як окремий соціально-рольовий статус, за допомогою якого можливо визначити соціальні можливості представників окремої статі в різних сферах життя, таких як професійна діяльність, доступ до освіти, влади чи наявності спеціальних сімейних ролей та репродуктивної поведінки $[8$, c. 8]. Ми не можемо погодитись із даною позицією, оскільки, виходячи із презумпції рівності, гендер не $\epsilon$ тим чинником, який дає підстави визначати наявність або відсутність в особи прав та можливостей на реалізацію таких прав.

Оцінюючи поняття гендерної рівності, українські науковці Т.М.Мельник та Л.С.Кобелянська зауважують, що це однакове забезпечення рівними правами жінок і чоловіків. Автори запевняють, що зміст цього поняття включає відсутність привілеїв за статтю, заборону дискримінації, а також свободу вибору, розвитку, пошуку [9, с. 194]. Цілком погоджуємось із даною позицією, 
а в цілому звернемо увагу на те, що такий підхід лежить в основі більшості дефініцій поняття «гендерна рівність». Разом із тим інші дослідники можуть розглядати дане питання у контексті різних особливостей цієї концепції.

На думку I. Р. Скалько, гендерна рівність - це концепція досягнення рівних прав між чоловіками і жінками у всіх сферах життя суспільства [10, c. 218]. Автором розглядається дане поняття крізь призму досягнутого результату діяльності щодо встановлення між представниками різних статей рівних прав у різних сферах життєдіяльності. Тобто, представники обох статей не лише мають забезпечуватись рівними правами, а й можливістю реалізовувати ці права у будь-якій сфері суспільного життя. Дана позиція $\epsilon$ досить слушною в контексті розуміння її як певної мети, якої необхідно досягти в процесі врегулювання прав та свобод чоловіків та жінок. Рівність же, в свою чергу, буде наявною лише в результаті такої діяльності.

К. Б. Левченко пропонує дещо ширше розуміння гендерної рівності як явища. На думку дослідниці, під гендерною рівністю слід розуміти рівні права і рівні можливості для жінок та чоловіків у суспільстві, рівні умови для реалізації прав людини, участь в національному, політичному, економічному, соціальному та культурному розвитку, отримання рівних винагород за результатами участі [11, с. 306]. Тобто, виділяється необхідність закріплення не лише рівних прав для різних статей, а й наголошується на важливості забезпечення реалізації відповідних прав у рівних умовах. Вченою виокремлено п'ять основних напрямів, за якими повинен бути впроваджений та забезпечений рівний доступ до реалізації прав і розвитку особи. Зокрема, до таких віднесено політичний, економічний, культурний та соціальний. Це означає, що не можна обмежувати гендерну рівність якоюсь однією сферою. Вона має забезпечуватись на різних рівнях та в різних сферах. Окрім того, гендерну рівність варто розглядати не лише як рівність у встановленні прав, але й рівність у можливостях їх реалізації

В. I. Барко під гендерною рівністю розуміє процес справедливого ставлення до жінок та чоловіків у суспільстві, забезпечення рівних прав і рівних можливостей для жінок і чоловіків, рівних умов для реалізації прав людини, участі в економічному, політичному, соціальному і культурному розвитку [12, с. 153]. Таким чином автор виділяє три основні напрями, в яких розкривається гендерна рівність, зокрема через ставлення до обох статей, надання їм рівних прав та можливостей, а також через забезпечення умов для їх реалізації. Вважаємо, що виділення умов для реалізації в окрему категорію $є$ необхідним, оскільки наголошує на актуальності їх забезпечення. Важливим відповідне забезпечення $€$ в аспекті можливої наявності унормованих прав, однак без можливості їх реалізації механізм закріплення $\epsilon$ неефективним.

У дослідженнях В. В. Кириченко віднаходимо визначення гендерної рівності як режиму діяльності у галузі прав людини, при якому особи різних статей наділяються рівними правами та можливостями для їх участі у всіх сферах суспільного, державного та приватного життя $[13$, с. 28]. Таким чином, гендерна 
рівність подається не просто як стан правового забезпечення, при якому особи різної статі наділені рівним обсягом прав, а як режим діяльності щодо такого забезпечення. Не можемо погодитись із даним твердженням, оскільки гендерна рівність, як складова частина принципу рівності, $\epsilon$ уособленням стану законодавства 3 належним забезпеченням рівних прав для представників різних статей. Водночас режим діяльності передбачає певні дії щодо впровадження такого стану законодавства. Отже, режим діяльності може бути застосований для визначення гендерної рівності лише під час встановлення стану законодавства, при якому така рівність буде забезпеченою.

0. М. Руднєва зазначає, що гендерна рівність - це принцип правового статусу (становища) людини в державі. Його складовими $\epsilon$ рівні права, свободи та обов'язки жінки i чоловіка; врахування особливостей (фізіологічних, психологічних тощо) статей у правовому регулюванні; система засобів гарантування рівності статей у державі [14, с. 107]. Таким чином авторка виділяє три основні напрями, завдяки яким можливе забезпечення гендерної рівності. Крім затвердження рівних прав, наголошується на необхідності наявності системи засобів гарантування рівності статей. Вважаємо, що дану систему слід розглядати як систему гарантування рівних можливостей у реалізації своїх прав представниками різних статей, оскільки без вступу у певні правовідносини відсутня можливість виділення рівності між особами.

Думку ж про врахування особливостей статей підтримують і інші вчені. Зокрема, зазначається про необхідність виокремлення гендер-ної рівності шляхом виділення відмінностей: як рівність статей не означає їх ототожнення одна з одною або ідентичність, як і те, що ця рівність не повинна встановлювати як норми такі умови та спосіб життя, які притаманні чоловікам $[12$, с. 154]. Погоджуємось із даною позицією, оскільки важливо закріпити не лише набір прав, який буде однаковим для різних статей, а й врахувати їх особливості для впровадження справедливого їх застосування з метою забезпечення розвитку особистості за різним напрямами. Відповідна позиція відповідає ряду необхідних прав, які закріплюються лише за жінками, та забезпечують їм важливі права, зокрема, право на материнство.

Про важливість врахування особливостей статей вказує i Н. М. Оніщенко Так, на думку автора, жінка й чоловік $\epsilon$ рівними, але відмінними, і вони рівноправні у своїй відмінності. Їхні відмінності - це особливості тієї чи іншої статі, що повинні бути враховані шляхом надання жінкам і чоловікам особливих груп прав і відповідних механізмів реалізації цих прав. Гендерні відмінності не $є$ перешкодою для рівності, їхнє існування вимагає диференціації законодавства, відбиття їх у спеціальних нормах. Надання жінці особливих прав порівняно з чоловіком i навпаки - чоловікові порівняно 3 жінкою, повинно мати чітке й вагоме підгрунтя у вигляді об'єктивних соціальних і природних відмінностей $[15$, с. 13]. Саме через необхідність надання певного, особливого набору прав, який продиктований об'єктивними відмінностями статей, гендерна рівність відрізняється від інших 
складових загального принципу рівності. Зокрема, інші предмети диференціації, такі як вік, раса чи національність, хоча й засновані на природних особивостях людей, однак не є підставою для надання їм окремих прав, які дозволяли б реалізацію таких особливостей відповідно до спеціального порядку.

Н. В. Грицяк пропонує розглядати гендерну рівність у чотирьох вимірах, які лежать в основі напрямів розвитку державної гендерної політики. Перший вимір - це права людини як стандарт політичних, громадянських, економічних, соціальних і культурних прав та свобод для жінок і чоловіків. Другий вимір - це права людини як права жінок. Третій вимір - рівність свобод, прав та обов'язків. Четвертий - рівні можливості - основний елемент тендерної рівності [16, с. 325-332]. Дана позиція, на нашу думку, не зовсім вдало розкриває суть гендерної рівності, оскільки другим виміром автор називає права жінок. Таким чином, зосереджуючи окрему увагу лише на правах однієї зі статей, досягнення рівності не $\epsilon$ можливим. Разом із тим, відповідне визначення розглядається крізь призму державної гендерної політики, яка на даному етапі запроваджується 3 метою набуття жінками тих самих прав, які $є$ у чоловіків, що в результаті забезпечить гендерну рівність. Отже, відповідне визначення можливе для використання лише на даному етапі розвитку вчення про рівність прав і свобод жінок та чоловіків в Україні, однак не є справедливим в контексті уявлень про рівність у цілому.

Досить широке розуміння поняття гендерної рівності пропонує M. I. Крочук Так, на думку автора, роз- глядати дану категорію слід через множину імплікацій, до яких віднесено: 1) рівність прав - що відповідає законодавчому закріпленню рівними правами осіб різної статі в усіх сферах життєдіяльності; 2) рівність можливостей - тобто надання особам чоловічої та жіночої статі однакових умов для використання й розподілу соціальних, економічних, культурних та політичних цінностей, що забезпечує відсутність дискримінації та обмежень до представників окремої статі; 3) забезпечення рівних умов для реалізації прав та можливостей; 4) «гендерну симетрію» - стан реалізації на практиці вищенаведених прав і можливостей представників різних статей [17, с. 469]. Даний підхід достатньо повно розкриває важливі моменти щодо надання рівних прав чоловікам та жінкам і забезпечення можливостей їх реалізації. Зокрема, йдеться про рівні права для представників різних статей, але не менш важливим моментом у цьому зв'язку $є$ надання не просто рівного, а справедливого набору прав. Саме справедливе розподілення прав, відповідно до особливостей кожної статі, на нашу думку, і є гарантією забезпечення гендерної рівності. Лише надання прав, без урахування природних та фізіологічних можливостей, $є$ таким самим порушенням, як і порушення принципу рівності.

Окрім наукової літератури, поняття «гендерна рівність» також знайшло своє закріплення у деяких нормативно-правових актах. На національному рівні вперше відповідне поняття було відображене в постанові Верховної Ради України «Про Рекомендації парламентських слухань «Становище жінок в Україні: реалії та перспективи» від 29 червня 
2004 року [18]. Згідно з нормами даного акта, гендерна рівність - це дотримання рівних прав чоловіків та жінок. Враховуючи наведені вище позиції вчених, у даній постанові дається досить вузьке розуміння гендерної рівності. Як нами було встановлено, гендерну рівність характеризує значно ширше коло ознак, у тому числі справедливість прав, гарантії їх забезпечення тощо. Тобто, у цілому Верховна Рада України розглядає питання гендерної рівності набагато вужче, ніж це притаманно вітчизняним дослідникам.

08 вересня 2005 р. Верховною Радою України було прийнято Закон України «Про забезпечення рівних прав та можливостей жінок і чоловіків» № 2866-IV. У цьому нормативноправовому акті міститься нове, більш досконале визначення гендерної рівності. 3 моменту набрання відповідним нормативно-правовим актом законної сили під гендерною рівністю на офіційному рівні прийнято розуміти рівний правовий статус жінок і чоловіків та однакові можливості його реалізації, що дозволяє особам обох статей брати рівну участь у всіх сферах життєдіяльності суспільства [2]. На нашу думку, дана дефініція $є$ більш вдалою та повною за попередню, однак водночас має певні недоліки. Позитивними моментами $€$ визнання законодавцем необхідності не лише закріплення рівних прав за особами, незалежно від їх статі, а й зосередження уваги на можливості їх реалізації. Окрім того, визначена мета гендерної рівності, а саме рівна участь у різних сферах життя осіб, незалежно від статі. Однак ми не можемо погодитись із тим, що гендерна рівність - це статус особи. Більш вдалим у даному контексті буде прив'язка гендерної рівності до стану законодавства, яке регулює відповідні правовідносини, а також до стану сприйняття даної категорії суспільством та відповідним руйнуванням стереотипів щодо моделей поведінки представників різних статей, адже гендерна рівність передусім має бути закріплена в актах законодавства і вже на основі відповідних норм реалізовуватись на практиці.

Тож проаналізувавши наукові та законодавчі підходи щодо визначення поняття «гендерна рівність», зробимо висновок, що під гендерною рівністю слід розуміти стан законодавства 3 належним забезпеченням рівних прав для представників різних статей, що уособлює систему гарантування рівних можливостей у реалізації своїх прав як чоловіками, так і жінками у всіх сферах життедіяльності суспільства із врахуванням особливостей кожної статі 3 метою економічного, політичного, соціального і культурного розвитку особистості.

Отже, забезпечення гендерної рівності по суті являє собою забезпечення рівності прав і свобод жінок та чоловіків в Україні. Л.В.Гонюкова відзначає не обхідність забезпечення гендерної рівності в контексті розуміння, наскільки ефективно країна будує об'єднане, розвинуте та поступальне суспільство. Вчена вказує, що рівень захищеності жінок $\epsilon$ відображенням рівня розвитку суспільства, відтак нівелювання наявності проблем гендерної рівності може поставити під удар усю систему державного управління $[19$, с. 116]. Ми не можемо не погодитись 3 відповідною позицією. Досягнення достатнього рівня гендерної рівності відображає 
стан впровадження та дії загального принципу рівності між особами, що $€$ однією із основ побудови суспільствва. Саме рівність може вважатись одним із гарантів досягнення гармонічного розвитку соціуму в країні. Щодо відображення рівня розвитку суспільства через досягнення рівня забезпечення гендерної рівності, можемо зауважити, що ще на початку минулого століття права жінок були значно вужчими. Однак з розвитком суспільства в усьому світі поступово дійшли думки про необхідність зрівняння в правах представників різних статей. Тезу по те, що захист гендерної рівності $\epsilon$ важливим обов'язком держави, підтримує i Т. М. Мельник, яка вказує, що рівність осіб, зважаючи на їх природні права, надані з народження, є предметом регулювання Конституції України [20, с. 31]. Отже, забезпечення рівності між жінками та чоловіками $\epsilon$ нагальною потребою, що відображає ступінь розвитку демократичного суспільства в країні. Відтак, очевидною $\epsilon$ необхідність забезпечення гендерної рівності. Тобто, забезпечення рівності прав i свобод жінок та чоловіків в Україні є наслідком тривалого історичного процесу. у нашій країні таке забезпечення відбулось із прийняттям Конституції України та встановленням у їі змісті спеціальних норм, які забезпечують гендерну рівність чоловіків та жінок. У подальшому питання забезпечення рівності прав і свобод жінок та чоловіків в Україні лише розши-рювалось і отримувало закріплення в інших нормативно-правових актах. Разом із тим поняття «забезпечення рівності прав і свобод жінок та чоловіків» так і не було визначено у науковій теорії нашої держави.
Так, Великий тлумачний словник сучасної української мови визначає слово «забезпечувати», як створення надійних умов для здійснення чого-небудь; гарантування чогось [21, c. 281]. Таким чином, з метою забезпечення гендерної рівності необхідним $€$ вжиття окремих заходів, які нададуть можливість створення належних умов та гарантування наявності гендерної рівності.

Як нами встановлено в даній роботі, під «забезпеченням» рівності прав і свобод жінок та чоловіків мається на увазі передусім правове забезпечення. Це ж підтверджується i дослідниками зазначеної сфери. Так, Т. Р. Деметрадзе зазначає, що забезпечення гендерної рівності бере свій початок із визнання даного принципу державою та запровадження відповідної регламентації нормативноправовими актами [22, с. 127]. Закріплення відповідного принципу на загальнодержавному рівні відіграє важливу роль у його забезпеченні, оскільки є від ображенням політики держави у даному напрямі. Впроваджуючи та розвиваючи гендерну рівність, держава окреслює вектор розвитку суспільства в середині країни, вказуючи на необхідність забезпечення гармонійного розвитку на базі рівності між людьми, зокрема без дискримінації на основі статі людини. Тому доходимо висновку, що забезпечення гендерної рівності доцільно розглядати в контексті правового забезпечення даного поняття.

Так, .I. Наливайко сприймає феномен «забезпечення прав людини» в ракурсі діяльності органів держави й місцевого самоврядування, громадських об'єднань і громадян зі створення умов (гарантій) для їх пра- 
вомірної та неухильної реалізації й захисту [23, с. 22]. Тобто, дослідник поряд із діяльністю суб'єктів владних повноважень до складу поняття правового забезпечення додатково включив встановлені державою гарантії, важливість яких для забезпечувального процесу полягає в тому, що вони, як система особливих умов i засобів, власне кажучи, і забезпечують реальність здійснення та реалізацію прав. Даний підхід $є$ цікавим 3 точки зору наукового дослідження, оскільки автор розглядає дефініцію правового забезпечення як сукупність встановлених гарантій реалізації прав та дій органів державної влади щодо безпосереднього застосування відповідних гарантій. Таким чином, звертається увага на необхідність самого встановлення гарантій та одночасного забезпечення їх реалізації з боку держави. У даному випадку гарантіями можуть виступати самі норми, які визначають те чи інше право, що в свою чергу впроваджує гарантію реалізації відповідного права. Водночас діяльність державних органів здійснюється 3 метою реалізації відповідних гарантій, встановлених нормативно-правовими актами.

Звертаючись до праць інших науковців, підкреслимо, що ними також відзначається лише частина необхідного змісту поняття правового забезпечення. У Великому тлумачному словнику сучасної української мови поняття правового забезпечення визначається як сукупність правових норм, що регламентують правові взаємини та юридичний статус [21, с. 375]. М. В. Цвік під правовим забезпеченням має на увазі цілеспрямовану дію на поведінку людей і суспільні відносини за допомогою правових (юридичних) засобів [24, c. 404]. Т. В. Збирак, вивчаючи питання права на свободу слова в Україні та $€ C$, визначає правове забезпечення як уніфіковану систему правових засобів утвердження, реалізації, охорони, захисту та відтворення цього права, що закріплені у нормативно-правових актах кожної конкретної держави-члена ЄC [25, с. 8]. Таким чином, науковцями звертається увага лише на частину змісту поняття правового забезпечення, а саме на нормативне закріплення прав осіб. На наш погляд, відповідні визначення $€$ недостатніми для повної характеристики дефініції поняття правового забезпечення.

Висновки. Враховуючи вищенаведене, вважаємо за доцільне визначити забезпечення рівності прав чоловіків та жінок як сукупність нормативно визначених гарантій щодо забезпечення рівних прав для представників різних статей, впровадження рівних можливостей у реалізації своїх прав як чоловіками, так і жінками у всіх сферах життєдіяльності суспільства із врахуванням особливостей кожної статі 3 метою економічного, політичного, соціального і культурного розвитку особистості, та діяльність органів державної влади зі створення умов, необхідних для відповідного забезпечення з боку держави.

\section{Список використаних джерел}

1. Конституція України: Закон України від 28.06.1996 р. № 254к/96-ВР.

2. Про забезпечення рівних прав та можливостей жінок і чоловіків: Закон України від 08.09.2005 р. № 2866-IV. 
3. Дутчак О. Гендерна нерівність та режим жорсткої економії в Україні посткризового періоду. URL: https: commons.com.ua/uk/genderna-nerivnist-ta-rezhimzhorstkoyi-ekonomiyi/ (дата звернення: 20.04.2019).

VIII.

4. Кодекс законів про працю України: Закон України від 10.12.1971 р. № 322-

5. Васильченко О. П. Гендерна рівність в Україні. Вісник Академії митної служби України. 2014. № 2. С. 46-53.

6. Кіммел Майкл С. Гендероване суспільство; пер. з англ. Майкл С. Кіммел. Київ : Сфера, 2003. 490 с.

7. Основи теорії гендеру: навч. посіб. / за ред. Агеєвої В. П., Кобелянської Л. С., Скорик М. М. Київ : К.І.С., 2004. 536 с.

8. Герасименко Т. В. Гендерні аспекти соціальної політики в Україні. Умань : СПД Сочинський, 2008. 252 с.

9. Мельник Т., Кобелянська Л. 50/50: Сучасне ґендерне мислення: словник. Київ : К.І.С., 2005. 280 с.

10. Скалько I. Р. Гендерна рівність, як основа демократичного суспільства. Актуальні проблеми природничих та гуманітарних наук у дослідженнях молодих учених «Родзинка - 2016» : зб. матеріалів XVIII Всеукр. наук. конф. молодих учених (м. Черкаси, 21-22 квітня 2016 р.). Серія Психолого-педагогічні науки Ч. 1 / МОН України, ЧНУ ім. Б. Хмельницького. Черкаси : Вид-во ЧНУ ім. Б. Хмельницького, 2016. С. 218-220.

11. Левченко К.Б. Гендерна політика в Україні: визначення, формування, управління. Харків : Вид-во Нац. ун-ту внутр. справ, 2003. 344 с.

12. Барко В. І. Теоретичні засади визначення поняття гендерної рівності в діяльності органів внутрішніх справ України на сучасному етапі розвитку суспільства. Вісник Національного університету оборони України. 2014. Вип. 4. С. 152-155.

13. Кириченко В. В. Адміністративно-правове забезпечення гендерної рівності в організації діяльності персоналу ОВС: дис. ... канд. юрид. наук. 12.00.07 / Харківський національний університет внутрішніх справ. Харків, 2011. 215 с.

14. Руднєва О. Гендерна рівність як принцип законодавства України. Право України. 2002. № 4. С. 104-108.

15. Оніщенко Н. М., Пархоменко Н.М. Правові засади формування та розвитку гендерного середовища в Україні : монографія. Київ : Юридична думка, 2010. 352 с.

16. Грицяк Н. Формування гендерної політики в Україні: проблеми теорії, методології, практики : монографія Київ : Вид-во НАДУ, 2004. 384 с.

17. Крочук М. I. Гендерна рівність як складова загального принципу рівності. Науковий вісник Львівського державного університету внутрішніх справ. (Серія юридична). 2011. № 4. С. 464-471

18. Про Рекомендації парламентських слухань «Становище жінок в Україні: реалії та перспективи»: постанова Верховної Ради України від 29.06.2004 р. № 1904-IV.

19. Гонюкова Л. В. Сучасний механізм упровадження гендерної політики в Україні. Вісник Національної академії державного управління при Президентові України. 2016. № 2. С. 114-120.

20. Гендерна експертиза українського законодавства (концептуальні засади) / відп. ред. Т.М. Мельник. Київ : Логос, 2001. 120 с.

21. Бусел В. Т. Великий тлумачний словник сучасної української мови. Київ, Ірпінь : Перун. 2005. 1728 с.

22. Деметрадзе Тамаз Ревазович. Конституційний принцип рівності прав жінки і чоловіка: поняття, зміст, механізм його реалізації та захисту : автореф. дис. ... канд. юрид. наук : 12.00 .02 / Держ. ВНЗ «Ужгород. нац. ун-т» М-ва освіти і науки України. Ужгород, 2015. 15 с. 
23. Наливайко О. І. Правовий захист людини як предмет дослідження загальної теорії права. Держава і право : зб. наук. праць. Юридичні і політичні науки. Вип. 12. Київ : Інститут держави і права ім. В.М. Корецького НАН України, 2001. С. 18-24.

24. Загальна теорія держави і права: підручник для студ. юрид. спец. вищ. навч. закладів освіти / М. В. Цвік, В.Д. Ткаченко, Л. Л. Богачова, О.В.Петришин, С. М. Олейников; М. В. Цвік (ред.). Харків : Право, 2002. 432 с.

25. Збирак Т. В. Адміністративно-правове забезпечення права на свободу слова в Україні та досвід Європейського Союзу : автореф. дис. ... канд. юрид. наук: 12.00.07 / Державний науково-дослідний інститут МВС України. Київ, 2014. 21 с.

\section{References}

1. Vasylchenko, O. P. (2014). Henderna rivnist v Ukraini. Visnyk Akademii mytnoi sluzhby Ukrainy, 2, 46-53 [in Ukrainian].

2. Aheieva, V.P., Kobelianska, L.S., Skoryk, M.M. (Red). (2004). Osnovy teorii henderu. Kyiv: «K.I.S.» [in Ukrainian].

3. Herasymenko, T. V. (2008). Henderni aspekty sotsialnoi polityky v Ukraini. Uman: SPD Sochynskyi. [in Ukrainian].

4. Melnyk, T. (2005) 50/50: Suchasne genderne myslennia: slovnyk. Kyiv : «K.I.S.» [in Ukrainian].

5. Skalko, I. R. (2016). Henderna rivnist, yak osnova demokratychnoho suspilstva. Aktualni problemy pryrodnychykh ta humanitarnykh nauk $u$ doslidzhenniakh molodykh uchenykh "Rodzynka - 2016" : zb. materialiv XVIII Vseukr. nauk. konf. molodykh uchenykh 21-22 kvitnia 2016 r. ChNU im. B. Khmelnytskoho. Cherkasy: Vydavnytstvo ChNU im. B. Khmelnytskoho [in Ukrainian].

6. Levchenko, K.B. (2003). Henderna polityka v Ukraini: vyznachennia, formuvannia, upravlinnia. Kharkiv : Vyd-vo Nats. Un-tu vnutr. sprav [in Ukrainian].

7. Barko, V. I. (2014). Teoretychni zasady vyznachennia poniattia hendernoi rivnosti $\mathrm{v}$ diialnosti orhaniv vnutrishnikh sprav Ukrainy na suchasnomu etapi rozvytku suspilstva. Visnyk Natsionalnoho universytetu oborony Ukrainy, 4, 152-155 [in Ukrainian].

8. Kyrychenko, V.V. (2011). Administratyvno-pravove zabezpechennia hendernoi rivnosti $v$ orhanizatsii diialnosti personalu OVS (Dis. kand. yurid. nauk). Kharkiv [in Ukrainian].

9. Rudnieva, O. (2002). Henderna rivnist yak pryntsyp zakonodavstva Ukrainy. Pravo Ukrainy, 4, 104-108 [in Ukrainian].

10. Onishchenko, N.M., Parkhomenko, N.M. (2010). Pravovi zasady formuvannia ta rozvytku hendernoho seredovyshcha $v$ Ukraini. Kyiv: Yurydychna dumka [in Ukrainian].

11. Hrytsiak, N. (2004). Formuvannia hendernoi polityky $v$ Ukraini: problemy teorii, metodolohii, praktyky. Kyiv : Vyd-vo NADU [in Ukrainian].

12. Krochuk, M. I. (2011). Henderna rivnist yak skladova zahalnoho pryntsypu rivnosti. Naukovyi visnyk Lvivskoho derzhavnoho universytetu vnutrishnikh sprav, 2, 464471 [in Ukrainian].

13. Honiukova, L. V. (2016). Suchasnyi mekhanizm uprovadzhennia hendernoi polityky v Ukraini. Visnyk Natsionalnoi akademii derzhavnoho upravlinnia pry Prezydentovi Ukrainy, 2, 114-120 [in Ukrainian].

14. Melnyk, T. M. (Red). (2001). Henderna ekspertyza ukrainskoho zakonodavstva (kontseptualni zasady). Kyiv : Lohos [in Ukrainian].

15. Busel, V. T. (Red). (2005). Velikij tlumachnij slovnik suchasnoyi ukrayinskoyi movi. Kiyiv; Irpin: VTF «Perun» [in Ukrainian].

16. Demetradze, T. R. (2015). Konstytutsiinyi pryntsyp rivnosti prav zhinky $i$ cholovika: poniattia, zmist, mekhanizm yoho realizatsii ta zakhystu. (Avtoref. dis. na zdobuttya nauk. stupenya kand. yurid. nauk). Uzhhorod [in Ukrainian]. 
17. Nalyvaiko, O.I. (2001). Pravovyi zakhyst liudyny yak predmet doslidzhennia zahalnoi teorii prava. Derzhava i pravo: zbirnyk naukovykh prats. Yurydychni $i$ politychni nauky, 12, 18-24 [in Ukrainian].

18. Tsvik, M. V. (Red). (2002). Zahalna teoriia derzhavy i prava: pidruchnyk dlia stud. yuryd. spets. vyshch. navch. zakladiv osvity. Kharkiv: Pravo [in Ukrainian].

19. Zbyrak, T. V. (2014). Administratyvno-pravove zabezpechennia prava na svobodu slova v Ukraini ta dosvid Yevropeiskoho Soiuzu. (Avtoref. dis. na zdobuttya nauk. stupenya kand. yurid. nauk). Kyiv [in Ukrainian].

S. Krugova. Postgraduate Student of the Institute of State and Law named after V. M. Koretsky NAS of Ukraine

ORCID: 0000-0002-5488-6754

\section{Scientific interpretation of providing of equal rights and freedom of women and men in Ukraine}

The purpose of the article is to formulate a scientific interpretation of ensuring equality of rights and freedoms of women and men in Ukraine. It is emphasized that the achievement of a sufficient level of gender equality reflects the state of implementation and action of the general principle of equality between individuals, which is one of the foundations of society. Equality can be considered one of the pillars for achieving a harmonious development of society in the middle of the country. Regarding the reflection of the level of development of society through the achievement of the level of gender equality, it can be noted that at the beginning of the last century women's rights were much narrower. It has been found that the concept of gender, as a set of specific characteristics and characteristics of a particular gender, is quite broadly understood, in particular in terms of the number and branching of the areas to distinguish the features that make up the meaning of gender. The main is to define the social role of a particular gender, which subsequently reflects on different areas of activity in the course of their life and becoming. It has been determined that gender equality should be understood as a state of legislation with adequate protection of equal rights for representatives of different sexes, which represents a system of guaranteeing equal opportunities in the exercise of their rights by both men and women in all spheres of society, taking into account the peculiarities of each gender for economic, political, social and cultural development of the individual. It has been proved that gender equality should be considered in the context of legal support for this concept. It is concluded that ensuring the equality of the rights of men and women should be defined as a set of normatively-defined guarantees for ensuring equal rights for representatives of different sexes, introduction of equal opportunities in the exercise of their rights by both men and women in all spheres of society, taking into account the peculiarities of each gender. with a view to the economic, political, social and cultural development of the individual, and the activities of public authorities to create the conditions necessary for the appropriate on the part of the state.

Keywords: legal acts; wages; personality; realization of rights; legal support. 